\title{
High-Dose Chemotherapy with Hematopoietic Stem Cell Transplantation for Patients with Advanced Multiple Myeloma
}

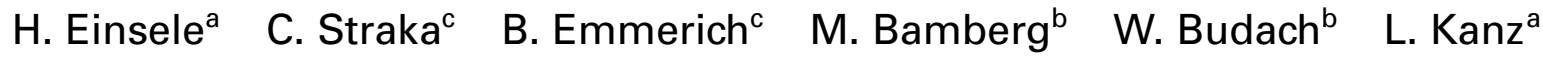 \\ ${ }^{a}$ Medizinische Klinik II und \\ ${ }^{\text {b }}$ Abteilung für Strahlentherapie, Radiologische Klinik, Eberhard-Karls-UniversitätTübingen, \\ ${ }^{c}$ Klinikum Innenstadt, Ludwig-Maximilians-Universität München
}

\section{Is High-Dose Chemotherapy and Autologous Stem Cell Transplantation the Standard Treatment for Multiple Myeloma?}

For many years, the Alexanian regimen with melphalan and prednisone (MP) has been considered the standard treatment for advanced myeloma. The response was about $40 \%$, the median duration of response 2 years, that of survival 3 years [1]. During recent years, combination regimens containing several alkylating agents, anthracyclines, and vinca alkaloids have been evaluated. Many of these regimens have been compared to MP in randomized studies [2,3], but no significant difference in survival was apparent between the two treatments.

However, since 1996 the standard treatment for untreated patients (and those with limited pretreatment) below 60 years of age with a good performance status is induction combination chemotherapy followed by high-dose chemotherapy with autologous stem cell support. The Intergroupe Français du Myélome (IFM 90 trial) has recently compared conventional chemotherapy with high-dose therapy supported by autologous bone marrow tansplantation (ABMT) [4].200 patients were randomized to receive either conventional chemotherapy (18 alternating cycles of polychemotherapy VMCP/VBAP) or high-dose therapy following 4-6 cycles of VMCP/VBAP. This consisted of high-dose melphalan at $140 \mathrm{mg} / \mathrm{m}^{2}$ and total body irradiation (8 Gy in 4 fractions) followed by ABMT. In this study, the highdose treatment was superior to conventional therapy in terms of overall ( $81 \mathrm{vs.} 57 \%)$ and complete ( $22 \mathrm{vs.} 5 \%$ ) response rates. The event-free (EFS) 28 vs. 10\%) and overall survival (OS) (52 vs. $12 \%$ ) at 5 years also were significantly superior in the highdose arm [5]. In a matched-pair comparison again the high-dose treatment was demonstrated to provide a superior EFS and OS when compared to conventional therapy [4].

\section{Should Patients Above the Age of 60 Receive High-Dose Therapy?}

Several groups [5-7] have shown the feasibility of high-dose chemotherapy and autologous stem cell transplantation
(ASCT) in selected patients above age 60 with advanced multiple myeloma, but the improved EFS and OS for high-dose treatment in the IFM 90 trial could only be confirmed for patients up to age 60 [4]. Thus, in the German Multiple Myeloma Study Group (DSMM) patients between age 60 and 70 are randomized to receive either conventional chemotherapy or high-dose melphalan treatment followed by ASCT to assess the efficacy and toxicity of high-dose treatment in this population. The results of this study should have a great impact not only for older multiple myeloma (MM) patients, but also for high-dose therapy studies in other clinical indications for patients above age 60. At the moment, patients above 60 years should receive high-dose chemotherapy only in clinical studies.

\section{How Could the Treatment Results of High-Dose Therapy be Improved?}

Several studies clearly have shown that the better the obtained post-transplant response, the longer the progression-free survival (PFS) and OS can be expected. Thus, to improve EFS and $O S$ the aim must be first to increase the complete remission (CR) rates beyond the $22 \%$ reported in the IFM 90 trial. Further dose intensification may be achieved by either performing tandem transplants after high-dose melphalan therapy [8-10] or by an intensified conditioning regimen followed by a single ASCT [11]. The role of tandem transplantation is being evaluated in the current IFM 94 trial, which randomizes patients to either a single or double high-dose procedure following induction therapy with VAD [12]. In a first interim analysis [12], patients showed a better EFS and OS when receiving double high-dose compared to single high-dose melphalan [12]. The superiority of a double versus a single high-dose regimen could be further confirmed in an Italian multicenter study [13]. To evaluate an intensified conditioning regimen followed by a single ASCT, 3 highly active components (irradiation, busulfan, and cyclophosphamide) were combined in a phase I/II trial [11]. To reduce hepatic and pulmonary toxicity of this intensified

\begin{tabular}{ll}
\hline KARGER & @ 2000 S. Karger GmbH, Freiburg \\
Fax +49 7614520714 & Accessible online at: \\
$\begin{array}{l}\text { E-mail Information@Karger.de } \\
\text { www.karger.com }\end{array}$ & www.karger.com/journals/onk
\end{tabular}

Prof. Dr. Hermann Einsele

Abteilung für Hämatologie/Onkologie, Medizinische Klinik,

Universität Tübingen

Otfried-Müller-Straße 10, 72076 Tübingen (Germany)

Tel. +49 7071 29-82808, Fax -3675

E-mail hneinsel@med.uni-tuebingen.de 
conditioning regimen, a modified total body irradiation (total marrow irradiation with shielding of liver and lung) and a reduced dosage of busulfan $(12 \mathrm{mg} / \mathrm{kg})$ were administered [14]. With a low transplant-related mortality (1\%), the main toxicity was mucositis WHO grade III/IV, a high rate of CR $(50 \%$ in patients with de novo multiple myeloma) could be achieved. Thus, tandem high-dose melphalan and this intensified conditioning regimen seem to be superior to a single high-dose melphalan or also a total body irradiation (TBI)/melphalan regimen. Therefore, in the DSMM patients up to age 60 are randomized to either receive tandem high-dose melphalan with double ASCT or an intensified conditioning regimen consisting of total marrow irradiation/busulfan and cyclophosphamide followed by a single ASCT.

\section{What is the Best Time for High-Dose Treatment: At Diagnosis or at First Relapse?}

Fermand et al. [14] reported the results of a randomized study comparing early high-dose treatment (HDT) versus late HDT after relapse following conventional therapy. In the late HDT arm several cycles of VMCP had been administered up to a plateau phase (median number of cycles, 7). At progression, patients received 3-4 cycles of VAMP followed by an intensified treatment combining TBI (12 Gy), cyclophosphamide $(60 \mathrm{mg} / \mathrm{kg})$, melphalan $\left(140 \mathrm{mg} / \mathrm{m}^{2}\right)$ and etoposide $\left(500 \mathrm{mg} / \mathrm{m}^{2}\right)$ supported by ASCT. In the early HDT arm, patients received 3-4 cycles of VAMP followed by the same intensive HDT as in case of late HDT. In both groups, autologous peripheral stem cells were collected at diagnosis after mobilization by CHOP. After HDT, all patients were proposed an interferon treatment. After a median follow-up of 42 months, the overall survival was not different in the two arms. The authors showed that time without symptoms and treatment (23 vs. 17 months in the early and late arm, respectively), as well as treatment toxicity were different in the two arms. The median survival post- transplantation was better in the early arm versus the late arm (61 vs. 28 months, respectively). Despite of the same OS, the authors recommended HDT in symptomatic MM patients early in the course of the disease.

\section{When Should an Allogeneic Stem Cell Transplantation be Performed?}

In younger patients ( $<55$ years), the therapeutic decision is also dependent on whether allogeneic bone marrow transplantation is an option or not. Tricot et al. [15] have reported the existence of a graft-versus-myeloma effect and this was in part confirmed by Björkstrand et al. [16]. In this European Blood and Marrow Transplantation Study matched-case study [16], the results of allogeneic bone marrow transplantation were compared to those following ABMT. The OS (34 vs. 18 months) and PFS were better in the autologous arm, but the difference was only apparent in male patients. The relapse and progression rate were significantly higher in autologous patients (2-year-relapse/progression rate 70 vs. $50 \%$ ), whereas the treatment-related mortality was higher in allogeneic patients (41 vs. 13\%). However, if only patients alive 1 year after transplantation were analyzed, PFS was better in the allogeneic arm (41 vs. 24 months). This study indicates that allogeneic bone marrow transplantation is more toxic but possibly more effective than autologous stem cell transplantation. There is no consensus advocating allogeneic or autologous transplantation in MM patients aged less than 55 years old with a sibling donor. It is a difficult situation in which a high risk of toxicity-related death must be weighed against higher efficacy. In the DSMM thus patients below age 55 - when an HLA-identical sibling donor is available - are offered allogeneic or autologous stem cell transplantation. Both patient groups receive the same induction and conditioning therapy, thus allowing to assess risks and benefits of allogeneic compared to autologous stem cell transplantation.

\section{References}

1 Alexanian R, Dimopoulos M: The treatment of multiple myeloma. N Engl J Med 1994;330:484-489.

2 Boccadoro M, Marmont F, Tribalto M, Avvisati G, Andriani A, Barbui T, Cantonetti M, Carotenuto M, Comotti B, Damacco F, et al.: Multiple myeloma: VMCP/VBAP alternating combination chemotherapy is not superior to melphalan and prednisone even in high-risk patients. J Clin Oncol 1991;9: 444-448

3 Gregory WM, Richards MA, Malpas JS, Boccadoro M, Marmont F, Tribalto M, Accisati G, Andriani A, Barbui T, Cantonetti M, Carotenuto M, Comotti B, Dammacco F: Combination Chemotherapy versus melphalan and prednisolone in the treatment of multiple myeloma: An overview of published trials. J Clin Oncol 1992;10:334-342.

4 Attal M, Harousseau JL, Stoppa AM, Sotto JJ, Fuzibet JG, Rossi JF, Fasassus P, Maisonneuve H, Facon T, Ifrah N, Payen C, Bataille R: A prospective, randomised trial of autologous bone marrow transplantation and chemotherapy in multiple myeloma. N Engl. J Med 1996;335:91-97.
5 Barlogie B, Jagannath S, Vesole DH, Naucke S, Cheson B, Mattox S, Bracy D, Salmon S: Superiority of tandem autologous transplantation over standard therapy for previously untreated multiple myeloma. Blood 1997;89:789-793.

6 Siegel DS, Desikan KR, Mehta J, Singhal S, Fassas A, Munshi N, Anaissie E, Naucke S, Ayers D, Spoon D, Vesole D, Tricot G, Barlogie B: Age is not a prognostic variable with autotransplants for multiple myeloma. Blood 1999;93:51-54.

7 Guba SC, Vesole DH, Jagannath S, Brcy D, Barlogie B, Tricot G: Peripheral stem cell mobilization and engraftment in patients over age 60. Bone Marrow Transplant 1997;20:1-3

8 Björkstrand B, Ljungman P, Bird JM, Saomson D, Gahrton G: Double high-dose chemoradiotherapy with autologous stem cell transplantation can induce molecular remission in multiple myeloma. Bone Marrow Transplant 1995;15:367-371.
9 Barlogie B, Jagannath S, Desikan KR, Mattox S, Vesole D, Siegel D, Tricot G, Munshi N, Fassas A, Singhal S, Mehta J, Anaissie E, Dhodapkar D, Naucke S, Cromer J, Sawyer J, Epstein J, Spoon D, Ayers D, Cheson B, Crowley J: Total therapy with tandem transplants for newly diagnosed multiple myeloma Blood 1999;93:55-65.

10 Straka C, Mitterer M, Oduncu F, Drexler I, Suttmann H, Christgau H, Adler S, Starck IM, Fischer N, Brack N, Hartenstein R, Kolb HJ, Nerl C, Coser P, Emmerich B: Modified total therapy with immunomagnetic B-cell purging of PBSC autografts in patients with multiple myeloma. Bone Marrow Transplant 1999;23(suppl 1):140.

11 Einsele H, Bamberg M, Budach H, Schmidt H, Schmidberger H, Trümper L, Löffler B, Schlimok G, Müller P, Oruzio M, Hertenstein B, Peest D, Metzner B, Frickhofen N, Zander A, Krüger N, Hossfeld D, Kanz L:Total marrow irradiation, busulfan and cyclophosphoamide followed by peripheral autologous PBSCT in patients with advanced multiple myeloma. Blood 1997;90(suppl 1):112a. 
12 Attal M, Harrousseau JL, Facon T, Michaux JL, Guilhot F, Fruchard C, Fuzibet JG, Hulin C, Caillo

D, Dorvaux V, Cahn CY, Grobois B, Stoppa AM, Ifrah N, Sotto JJ, Pignon B, Payen C: Single versus double transplant in myeloma: A randomized tria of the 'intergroup français du myélome' (IFM). Blood 1999;94(suppl 1):714a.

13 Tosi P, Cavo M, Zamagni E, Ronconi S, Benni M, Tura S: A multicentric randomized clinical trial comparing single vs. double autologous peripheral blood stem cell transplantation for patients with newly diagnosed multiple myeloma: results of an interim analysis. Blood 1999;94(suppl 1):715a.
14 Fermand JP, Ravaud P, Chevret S, Divine M, Leblond $\mathrm{V}$, Belanger $\mathrm{C}$, Macro $\mathrm{M}$, Pertuiset $\mathrm{E}$, Dreyfus F, Mariette X, Boccacio C, Brouet JC: Highdose therapy and autologous peripheral blood stem all transplantation in multiple myeloma: Up-fron or rescue treatment? Results of a multicenter sequential randomized clinical trial. Blood 1998;92 3131-3136.

15 Tricot G, Vesole D, Jagannath S, Hilton J, Munshi N, Barlogie B: Graft-versus-myeloma effect: Proof of principle. Blood 1996;87:1196-1198.
16 Björkstrand B, Ljungman P, Svensson H, Hernans J, Alegre A, Apperley J, Blade J, Carlson K, Cavo M, Ferrant A, Goldstone AH, de Laurenzi A, Majolino I, Marcus R, Prentice HG, Remes K, Samson D, Sureda A, Verdonck LF, Volin L, Gahrton G: Allogeneic bone marrow transplantation versus autologous stem cell transplantation in multiple myeloma: A retrospective case-matched study from the European Group for blood and marrow transplantation. Blood 1996;88:4711-4718. 